\section{North American Willow Cut-stem Growers: A Survey of the Business Identities, Production Practices, and Prospective for the Crop}

\author{
Margaret M. Saska ${ }^{1,2}$, Yulia A. Kuzovkina ${ }^{1,3,5}$, and \\ Robert M. Ricard ${ }^{1,4}$
}

ADDITIONAL INDEX WORDs. specialty flower, woody florals, precocious flowering, Salix

Summary. To assess the current state of willow ( Salix) cultivation for specialty cut flower production, a mail survey following the tailored design method polled willow growers in North America $(n=52)$. The instrument posed questions on business identity and cultural practices, including plant spacing, fertilization, irrigation, and pruning methods. A $69 \%$ response rate was achieved. The general grower profile was of a specialty cut flower producer with multiple years of experience growing willows. For the majority of respondents, willow was a supplemental source of income, complementing a larger product selection of woody and herbaceous species for cut flower production with annual sales for the crop of less than $\$ 25,000$. The majority of producers had a generally positive outlook on this crop as growers expressed strong support for the importance of willow in their product selection, for customer satisfaction, as well as for future intentions to increase production acreage, and even to extend seasonal markets. However, the non-scientific nature of willow production was revealed by wide variations in basic cultural practices and by very limited use of scientific plant names by the growers and frequent inability to accurately identify their selections, as well as the identification of growers' own personal experience as a main source of knowledge. The results of this survey helped researchers to identify a set of questions to improve the understanding of the fundamentals of willow production through the development of precise commercial production practices, standardization of variety names, and stimulation of further development of this crop through market expansion.

$\mathrm{P}$ roduction of woody ornamental cut stems represents a specialty niche in cut flower and a viable third crop enterprise (Stahl, 2004). Woody plants with colorful or unusually shaped stems, buds, flowers, or fruits have potential as an off-season production option (Stahl, 2004). They offer the unique benefits of season extension, financial returns during off-season time, hardiness, and multiple harvests from single plantings. The potential to significantly expand the market of woody cut stems has been recognized (Armitage and Laushman, 2003; Greer and Dole, 2008). However, woody floral

\footnotetext{
${ }^{1}$ Department of Plant Science, Unit 4067, University of Connecticut, Storrs, CT 06269

${ }^{2}$ Former Graduate Research Assistant, Department of Plant Science and Landscape Architecture, University of Connecticut, Storrs, CT 06269

${ }^{3}$ Assistant Professor, Department of Plant Science and Landscape Architecture, University of Connecticut, Storrs, CT 06269

${ }^{4}$ Senior Extension Educator, Department of Extension, University of Connecticut, West Hartford, CT 06117

${ }^{5}$ Corresponding author. E-mail: jkuzovkina@uconn. edu.
}

crops have received little formal research attention to determine the best cultural practices for optimal yields (Josiah et al., 2004).

Willow is among the most popular woody genera used for cut stem production (Armitage and Laushman, 2003; Bachmann, 2002; Byczynski, 2008; Greer and Dole, 2008). Willow species and varieties grown for cut stems exhibit a range of unique ornamental attributes, including showy catkins, brightly colored stems, as well as contorted or fasciated stem shapes. Willows, valued for showy precocious catkins, are typically harvested during the late winter months, while little else is available in field production of temperate climates. The seasonality of the crop makes it a natural complement to a wider crop selection. Because the branches are harvested in a late dormant state, they do not require maintenance before sales. Good cash returns, up to $\$ 1.25$ to $\$ 1.75$ per stem for willow species harvested for ornamental catkins, has been previously reported (Gouin, 1990), and annual gross financial returns for willow plants, up to $\$ 24.94$ per plant, is much higher than for many other woody florals (Josiah et al., 2004). Its relative ease of propagation, cultivation, and shipping, along with a long shelf life, make willow an attractive choice to expand a selection of woody cuts.

Even though willows are among the most common woody cut stems filling an important niche in the cut branch market (Armitage and Laushman, 2003), limited information is available about the extent of its cultivation and production practices. Some references provide basic descriptions of plant needs, with rather brief and various cultural recommendations (Bachmann, 2002; Byczynski, 2008; Gouin, 1990; Myers, 2004; Stahl, 2004). Therefore, this study was designed to poll willow cut stem producers in North America to address the following objectives: to characterize the extent of willow cultivation by identifying active willow growers' profiles, their production acreages, and gross sales; to evaluate consistency in production practices; to assess the prospective market value for the crop expansion, and to determine the need for further research.

\section{Materials and methods}

A mail survey was conducted that was comprised of 34 items, including 27 closed-ended and five openended questions and six opinion-based, closed-ended questions structured on a five-point scale (Likert, 1932). The first set of questions included inquiries regarding respondents' demographics, their production acreage, economic value of the crop (pricing and gross sales), and sales outlets. The

\begin{tabular}{llll}
\hline $\begin{array}{l}\text { Units } \\
\begin{array}{l}\text { To convert U.S. to SI, } \\
\text { multiply by }\end{array}\end{array}$ & U.S. unit & SI unit & $\begin{array}{l}\text { To convert SI to U.S., } \\
\text { multiply by }\end{array}$ \\
\hline 0.4047 & $\mathrm{acre}(\mathrm{s})$ & $\mathrm{ha}$ & $2.471 \mathrm{l}$ \\
0.3048 & $\mathrm{ft}$ & $\mathrm{m}$ & 3.2808 \\
1.1209 & $\mathrm{lb} / \mathrm{acre}$ & $\mathrm{kg} \cdot \mathrm{ha}^{-1}$ & 0.8922
\end{tabular}


second set of questions was designed to identify common production practices and included technical inquiries about species/varieties in cultivation, planting techniques, irrigation and fertilization management, pest and disease problems, harvest practices, and crop yields. The third set of questions asked the importance of the product in overall selection, market demand, customer satisfaction, and growers' perceptions on the expansion of the crop.

The survey was mailed in Nov. 2007 to members of the Association of Specialty Cut Flower Growers (ASCFG) who identified themselves as willow providers in the 2007 ASCFG Sourcebook. A list of additional willow growers was provided by L. Greer, an ornamental woody cut stem researcher. A total of 52 recipients were identified by these sources.

Survey contact materials and sequencing followed the tailored design method (Dillman, 2000). A fourwave mailing was implemented that sent each component at weekly intervals. A fifth contact, made by telephone, was implemented to prompt survey returns of non-respondents. Each contact emphasized the confidentiality of respondents' identities.

After all five contacts, 36 surveys were returned, yielding a $69 \%$ response rate. Of these, six returned surveys were incomplete or improperly completed. In total, 30 completed surveys were eligible for tabulation.

Survey data were analyzed using the univariate procedure of SAS (PC SAS version 9.1; SAS Institute, Cary, NC) for simple descriptive statistics. Survey sample size was restricted by the number of growers in willow production; the low population and sample size resulted in increased sampling error affecting overall survey accuracy. Missing and incomplete responses were excluded from calculation, resulting in small variation between sample size analyses between questions.

\section{Results and discussion}

Grower Profile. Survey respondents resided in 16 states located across the United States, as well as in two Canadian provinces. The highest concentrations of growers were located in Oregon (5) and North Carolina (5). Other states with a few willow growers included California (3) and Pennsylvania (2), and a single grower per state was identified for the following states: Connecticut, Georgia, Illinois, Indiana, Maryland, Massachusetts, Michigan, New Jersey, Tennessee, Vermont, Virginia, Washington, and for two provinces in Canada: British Columbia and Ontario. The absence of willow growers in the center of the continent was probably a reflection of the survey respondents' location rather than the actual range of suitable willow growing conditions.

The majority of respondents identified themselves as small-scale cut flower producers. Over $24 \%$ of respondents were large-scale specialty cut flower growers, followed by organic vegetable and traditional vegetable growers (Table 1). The remaining growers classified themselves as medium-scale producers, a cut floral greens grower, a vegetable and specialty cut flower grower, and a hobby grower. In addition to willow, 96.6\% of survey respondents produced other woody stems, and $79.3 \%$ produced additional herbaceous species for cut flower production. Only $11.1 \%$ of growers had more than 5 acres in production, while the majority $(55.5 \%)$ grew willow on less than 0.5 acre. Annual gross sales of willow cut stems were less than $\$ 25,000$ for most growers, supporting its recognition as a secondary crop, although there were seven growers $(24.1 \%)$ who consider willow as their major crop. Crop seasonality was emphasized by $20.7 \%$ of respondents, who indicated willow as a "major spring item," or the "only crop at that time of year."

Table 1. Selected business profiles, sales type, and growing practices of surveyed willow producers in the United States and Canada.

Respondent characteristic

Respondents selecting

Grower identification $(\mathrm{n}=29)$

Small-scale cut flower producers each choice (\%)

Large specialty cut flower growers

58.6

Organic vegetable growers

24.1

Traditional vegetable growers

10.3

Others

3.4

17.2

Willow yearly gross sales $(\mathrm{n}=29)$

$<\$ 25,000$

79.3

$\$ 25,000-50,000$

17.2

$\$ 50,000-100,000$

The importance of willow cut stem production $(\mathrm{n}=29)$

Major crop

24.1

Secondary crop

51.7

Experimental crop

3.4

Other

20.7

Years of experience with the crop $(\mathrm{n}=28)$

$<5$

17.8

5-10

42.8

$>10$

14.2

$>15$

25.0

Number of employees at peak season $(\mathrm{n}=30)$

1-2

50.0

3-6

$>6-10$

$>10$

Saleable product $(\mathrm{n}=30)$

Fresh and dry

56.7

Fresh stems

Dry stems

Sales outlet $(\mathrm{n}=30)$

Wholesale

Retail

Farmers' market

60.0

Other

10.0 
During willow harvest, half of the growers relied on a limited number of one or two employees, and among the growers, 30\% did it by "self," while one grower practiced "plus u-pick" harvesting, and only two growers employed more than six people. The majority of respondents sold fresh and dried stems using multiple outlets, where the most popular sales outlets included wholesale, followed by farmers' markets, and retail. Other outlets identified included flower auctions, discount craft stores, flower shows, and local subscription sales. The levels of growing experience varied, with the majority $(82.02 \%)$ of growers having more than 5 years of experience, followed by $39.2 \%$ of growers having more than 10 years of experience growing willow.

The typical grower profile is one of a specialty cut flower producer, with multiple years of experience with the crop, offering it as part of a larger product selection of ornamental cut stems. For the majority of respondents, willow is a supplemental source of income, complementing a larger product selection of woody stems and herbaceous species for cut flower production.

SPECIES / VARIETIES IN Cultivation. An open-ended question asked respondents to list willow species and varieties in production, preferably using scientific names. Common and botanical names were used to classify and tally the species/ varieties (Table 2). Only one grower identified all willow by their scientific names. Five growers used scientific names for a few species/varieties, while the rest of the species/varieties were identified only by common names. The remaining growers identified their selections by only common names, and some names were unique to the grower. The most commonly produced species included curly willow ( $S$. matsudana and its varieties), pink pussy willow (S. caprea), japanese fantail willow ( $S$. udensis 'Sekka'), japanese pussy willow ( $S$. chaenomeloides), and black pussy willow ( $S$. gracilistyla var. melanostachys). Only two growers listed American pussy willow ( $S$. discolor), and one golden willow (S. alba 'Vitellina'). Twelve references were made to "pussy willow," making it difficult to interpret the responses, as several species/varieties exhibit the "pussy willow" effect. The same imprecise identification referred to "curly willow" identified by 21 growers without referring to a specific species or variety. Seven growers used unknown common names that were descriptive of physical attributes or original location of the crop. Others indicated species/varieties that appeared selfnamed (Oscar or Engstrom) or were unidentifiable (for example, S. cilliana). Most respondents (70\%) grew five or fewer species/varieties, $23.4 \%$ grew six to 10 species/varieties, and one respondent grew 12 to 17 species/varieties.

Cultivation practices. Extensive descriptive information of production practices was collected from respondents (Table 3 ). Site preparation consisted of various techniques, including tilling as the most common

Table 2. Willow species and varieties in cut-stem production as identified by surveyed willow producers in the United States and Canada.

\begin{tabular}{lc}
\hline Willow species/varieties as they were named by growers & Growers (no.) \\
\hline Curly & 21 \\
Green curly & 6 \\
Scarlet curls (red curly) & 9 \\
Golden curls & 4 \\
'Snake' & 1 \\
Pink pussy willow, french red & 11 \\
Japanese pussy willow & 8 \\
Fantail willow, fasciated willow & 10 \\
Black pussy willow, black catkin & 7 \\
'Flame' (red) & 4 \\
American pussy willow & 2 \\
Golden willow & 1 \\
Pussy willow & 12 \\
Other & 14 \\
\hline
\end{tabular}

method, followed by herbicide applications and weed barrier, while some growers used combinations of these techniques. The material for plant establishment ranged from 0.5 to 3 $\mathrm{ft}$-long unrooted cuttings planted directly into a prepared field, to rooted cuttings 1 to $2 \mathrm{ft}$ long, to finished pot-grown plants. Spacing between plants within rows varied widely, but $58.6 \%$ of respondents preferred spacing greater than $4 \mathrm{ft}$ on center. The spacing between rows ranged from 10 to $14 \mathrm{ft}$. When respondents were asked whether they had various plant spacing within their crop and, if so, which spacing produced the higher yield, their perceptions were conflicting: $18.8 \%$ felt that denser spacing meant higher yield, $36.4 \%$ felt less denser spacing resulted in higher yield, and $36.4 \%$ did not notice differences in yield.

Fertilization practices also varied among growers, with $26.7 \%$ of respondents who did not fertilize their plantings. Thirty percent of growers used organic fertilizer, including chicken manure, cottonseed meal, compost, or feather meal. The formulations and rates of inorganic fertilizers indicated by 10 growers varied $(20 \mathrm{~N}-8.7 \mathrm{P}-16.6 \mathrm{~K}, 19 \mathrm{~N}-8.3 \mathrm{P}-$ $15.8 \mathrm{~K}$, or $18 \mathrm{~N}-7.9 \mathrm{P}-14.9 \mathrm{~K}$ at 200 $\mathrm{lb} /$ acre to $18 \mathrm{~N}-7.86 \mathrm{P}-14.9 \mathrm{~K}$ at 100 $\mathrm{lb} / \mathrm{acre})$. Others gave answers that were difficult to interpret (" $10 \mathrm{~N}$ $8.7 \mathrm{P}-16.6 \mathrm{~K}$ applied by hand in early spring" or " $1 \mathrm{~N}-0.4 \mathrm{P}-0.8 \mathrm{~K}$ organic, granular"). Nearly $43 \%$ of growers did not irrigate their plantings, and $35.7 \%$ irrigated only occasionally. Methods of weed control included mowing as the most common practice, herbicide applications were ranked next, followed by manual hand labor. Other methods included mulching, tractor cultivating, dense planting, or weed barrier. The majority of growers indicated that it took 3 to 5 years to reach full production after planting. Deer (Odocoileus spp.), japanese beetle (Popillia japonica), and willow leaf beetle (Plagiodera versicolora) were identified as the most frequent pest problems with willow plantings, followed by rabbits (Sylvilagus spp.), mice and voles (order Rodentia), and sawflies (Nematus oligospilus). Other minor pests included aphids (family Aphidoidea), moose (Alces alces), and elk (Cervus canadensis). The most frequent 
Table 3. Selected production practices of surveyed willow growers in the United States and Canada. Due to the variety of multiple cultural practices indicated by respondents, some percentages total greater than $100 \%$.

\section{Practices}

Respondents selecting

Site preparation

Tilling each choice $(\%)$

Herbicide application

65.6

Weed barrier

No preparation

31.0

17.2

17.2

Other

17.2

Spacing [distance between plants within a row $(\mathrm{ft})]^{\mathrm{z}}$

Less than 1

6.9

$1-4$

4-6

$6-10$

27.6

44.8

10 and more

3.5

Other

10.3

17.2

Fertilization

Did not fertilize

26.7

Organic

30.0

Nonorganic

23.0

Did not matter, no preference for organic or nonorganic formulations

Irrigation

Never irrigated

42.9

On a regular basis

Only during dry spells

21.4

35.7

Weed control

Mowing

62.0

Herbicide

53.3

Weed wack

Hoeing or hand pulling

Other

36.7

33.3

43.3

Years to reach full production

2-3

3-5

33.3

60.0

Did not know

10.1

Pests

No problems

20.7

Deer

Japanese beetle

34.5

34.5

Willow beetle

13.8

10.3

Rabbits

Mice

6.8

Willow sawfly and other caterpillars

6.8

Other

34.5

Diseases

No disease

27.6

Tip dieback

48.3

Other

24.1

Harvest technique

Coppice

82.0

Selective

77.0

Harvest with showy catkins based on

Plant stage between bud swell to bud burst

23.3

Plant stage between bud burst and catkin expansion

63.3

Calendar day of year

6.7

Other

6.7

Criteria used for grading and pricing Stem length disease was "tip dieback" observed by $48.3 \%$ of respondents, and $27.6 \%$ experienced no disease problems.

Coppicing (the hard pruning of woody plant material at the base of a plant) and pollarding [when branches are cut back to form a "head" with multiple shoots growing from a trunk (Brickell and Joyce, 1996)] were two ways of harvesting identified by respondents. The majority of growers $(82 \%)$ indicated the use of the coppicing technique. Some growers indicated that cutting down to a height of 3 to $4 \mathrm{ft}$ eased manual harvesting. Additionally, $77 \%$ of respondents indicated that they harvested branches selectively, and three of those growers returned later to coppice the entire plant. Species-specific pruning practices and multiple species/varieties grown by respondents meant that a single grower could potentially use more than one pruning practice on their farm in a species-appropriate manner.

Harvest time for catkin production peaked in February and March, and was based on the observations of plant developmental stages ranging from bud swell to bud burst, or to catkin expansion for the majority of growers. Harvest of colorful stems peaked from November through February, and the timing for harvest of colorful stems was determined by optimal stem color for $41.2 \%$ of respondents, while $26.6 \%$ of growers harvested any time after leaf drop. A few growers practiced year-round harvesting and sales of these species/varieties, including foliated stems in summer. Stem length was the most common criteria used for grading and pricing, followed by overall quality, catkin density, and stem color. In the category "other," the degree of stem fasciation or artistic shapes were recognized.

Almost all of the respondents relied on informal information or trial and error experiences for their cultural decisions, and "shared information" was indicated as the second learning resource. Grower meetings, articles, books, and the internet were selected as sources of information. Growers' production inquiries and concerns ranged from weed control, plant spacing, fertilization and pruning practices, to insect control and tip dieback, postharvest practices, and additional selections of ornamental 
Table 3. (Continued) Selected production practices of surveyed willow growers in the United States and Canada. Due to the variety of multiple cultural practices indicated by respondents, some percentages total greater than $100 \%$.

\begin{tabular}{lc}
\hline Practices & $\begin{array}{c}\text { Respondents selecting } \\
\text { each choice (\%) }\end{array}$ \\
\hline Overall quality & 69.0 \\
Catkin density & 58.6 \\
Color & 44.8 \\
Other & 6.9 \\
Sources of information & \\
Grower own experiences & 96.4 \\
Shared information & 57.1 \\
Grower meetings & 39.3 \\
Articles & 39.3 \\
Books & 17.8 \\
Internet & 7.0 \\
\hline
\end{tabular}

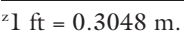

woody cuts. Catkin density and uniformity along the stems was a production concern reported by two growers, as some stems have "skips" or irregular sets of floral buds that make them less attractive for sales.

Crop potential. Questions regarding growers' perceptions of their willow cut stem offerings were addressed in the survey (Table 4). The majority of respondents $(53.6 \%)$ considered willow to be an important part of their product selection. The statement that "demand for willow stems is easily met by current plant stock" was favored by $38.4 \%$ of growers, while $42.4 \%$ of respondents disagreed with this statement, indicating that demand was greater than their production.

The statements addressing future plans for dedicated land for willow production further supported the perception of greater demand as $57.1 \%$ of growers planned to increase willow production acreage in the future, while the majority of respondents $(65.4 \%)$ had no plans to decrease production. The majority, 92.3\% of respondents, indicated overall customer satisfaction with willow cut stems. Slightly more than half $(53.9 \%)$ agreed to have a year-round market for willow stems if storage facilities allowed.

\section{Conclusions}

The recent establishment of the U.S. Department of Agriculture (USDA) Specialty Crop Initiative presents an opportunity to explore various value-added crops and to understand their importance and possibilities for expansion (USDA, 2008). This investigation of willow for specialty cut flower production suggests its potential as a secondary crop with unique harvest time supplementing larger product selections. Extended harvest time over many months of the year was recorded based on ornamental attributes. For some growers, production was predicated on organic principles and was sustainable for many years from initial planting, requiring only basic input.

Grower attitude toward the crop indicated an overall level of satisfaction with willow production based on their inclination toward increasing production of willows, rather than decreasing production, and to extending its markets to year-round delivery. However, the results of this survey revealed a rather non-scientific nature of willow production compared with other cut-stem crops.

Byczynski (2008) stated that because few recommendations exist for woody plants grown as cut flowers, producers have to use their own best judgment. This investigation confirmed that willow growers have developed their own techniques of growing willows using a system of trial and error and indicated their own personal experiences as a main source of knowledge. The majority of respondents did not identify their crops by scientific names, and in some cases, the cultivated varieties were difficult to determine. Very different and often ambiguous cultivation procedures were identified, revealing a lack of standard production technology.

There were discrepancies among growers on how plant spacing in the field affects product quality and yields. Similar inconsistencies were found in published literature: some sources supported the view that less density is more desirable (Bachmann, 2002; Gouin, 1990; Stahl, 2004), while scientific experiments have shown

Table 4. Surveyed willow growers' perceptions of willow cut stem production in the United States and Canada.

\begin{tabular}{|c|c|c|c|c|c|c|}
\hline \multirow[b]{2}{*}{ Statement } & \multicolumn{5}{|c|}{ Proportion of respondent for each category (\%) } & \multirow[b]{2}{*}{$\begin{array}{c}\text { Mean } \\
\text { rank }\end{array}$} \\
\hline & $\begin{array}{l}\text { Strongly } \\
\text { agree } 5\end{array}$ & 4 & 3 & 2 & $\begin{array}{c}\text { Strongly } \\
\text { disagree } 1\end{array}$ & \\
\hline $\begin{array}{l}\text { The demand for my willow stem is easily met by my } \\
\text { current plant stock. }\end{array}$ & $26.9 \mathrm{a}$ & $11.5 \mathrm{a}$ & $19.2 \mathrm{a}$ & 26.9 a & $15.5 \mathrm{a}$ & 3.08 \\
\hline I plan to decrease my willow production in the future. & $3.8 \mathrm{c}$ & $0.0 \mathrm{c}$ & $30.8 \mathrm{ab}$ & $7.7 \mathrm{abc}$ & $57.7 \mathrm{a}$ & 1.85 \\
\hline My customers are happy with my product. & $65.4 \mathrm{a}$ & $26.9 \mathrm{ab}$ & $7.7 \mathrm{bc}$ & $0.0 \mathrm{c}$ & $0.0 \mathrm{c}$ & 4.58 \\
\hline $\begin{array}{l}\text { If storage procedures allow, I would have a year-round } \\
\text { market for my willow stems. }\end{array}$ & $34.6 \mathrm{a}$ & $19.3 \mathrm{a}$ & $30.7 \mathrm{a}$ & $7.7 \mathrm{a}$ & $7.7 \mathrm{a}$ & 3.65 \\
\hline
\end{tabular}


that increased plant density yields larger stems and a significantly larger number of stems per unit area (Armitage and Dirr, 1995). The overall effect of plant spacing on willow stem production is not well understood and needs to be further investigated.

Further research is also necessary to determine the optimal fertilization levels and its effect on stem quality and yields. Specific fertilization practices have been previously recommended for some varieties (Armitage and Dirr, 1995; Gouin, 1990). Some references linked fertilization levels and stem length to catkin set (Armitage and Laushman, 2003; Myers, 2004), while others concluded that fertilization rates had little effect on stem quality, but rather rainfall was a more influential factor in determining stem quality (Bir and Conner, 2006). Insufficient water has been cited as responsible for poor quality stems for some species (Armitage and Laushman, 2003; Gouin, 1990). Additional research is also needed to determine the effect of irrigation on quality and yield.

Further investigations should also address species-specific pruning techniques. Generally, hard pruning in late winter has been previously recommended for many varieties (Armitage and Laushman 2003; Byczynski, 2008; Gouin, 1990; Kuzovkina and Quigley, 2004; Myers, 2004; Newsholme, 1992). However, a 3-year study found that hard pruning did not always improve stem yield and quality for japanese pussy willow compared with unpruned control treatments, and dormant harvest or June pruning increased length and quantity of corkscrew willow stems (Dole et al., 1997). Plant habit (shrub or tree form) is an important factor to consider when choosing pruning techniques (Greer and Dole, 2008).

In lieu of a technical reference to disseminate science-based information, these production issues should be considered to expand understanding and to foster maximum production. Field recommendations for plantation design must be clearly established to maximize yield, to improve plant health and ease of harvest, and for field maintenance. Commercial practices should also be focused on improving the quality of floral displays. Furthermore, the standardization of variety names is recommended. The preceding list of varieties is not exhaustive, and further diversification of the selections is suggested as the sales for cut stems are driven by novel varieties. As the popularity of farmers' markets and locally grown crops are rising, there are opportunities to market willow at those venues and to promote this crop as complying with the principles of ecological sustainability.

\section{Literature cited}

Armitage, A.M. and J.M. Laushman. 2003. Specialty cut flowers, 2 nd ed. Timber Press, Portland, OR.

Armitage, A.M. and M.A. Dirr. 1995. Influence of spacing on yield of Buddelia and Salix grown as cut flowers and stems. J. Environ. Hort. 13:176-177.

Bachmann, J. 2002. Woody ornamentals for cut flower growers. 23 Nov. 2009. <http://attra.ncat.org/attra-pub/PDF/ woodyornamentals.pdf $>$.

Bir, R. and J. Conner. 2006. Growing pussy willows for cuts. GMPro 26(5): 37-38.

Brickell, C. and D. Joyce. 1996. American Horticultural Society pruning and train- ing (American Horticultural Society practical guides). DK Publishing, New York.

Byczynski, L. 2008. The flower farmer, 2nd ed. Chelsea Green Publishing, White River Junction, VT

Dillman, D.A. 2000. Mail and internet surveys, 2nd ed. Wiley, New York.

Dole, J.M., J.C. Cole, and V. Stamback. 1997. Pruning method influences stem length and number of four woody cut species. HortScience 32:484 (Abstr.).

Gouin, F.R. 1990. Pussy willows as an alternative crop. Veg. Views Nwsl. 1:5-7.

Greer, L. and J. Dole. 2008. Woody cut stems for growers and florists: Production and post-harvest handling of branches for flowers, fruit, and foliage. Timber Press, Portland, OR.

Josiah, S.J., H. Brott, and J.R. Brandle. 2004. Producing woody floral products in an alleycropping system in Nebraska. HortTechnology 14:203-207.

Kuzovkina, Y. and M.F. Quigley. 2004. Selection of willows for floral and stem quality. HortTechnology 14:415-419.

Likert, R. 1932. A technique for the measure of attitudes. Arch. Psychol. 140:5-55.

Myers, R.D. 2004. Pussy willow: An alternative crop? Production Pointers 6(2):1-3. 23 July 2008. <http://www. agnr.umd.edu?AGNRNews? Article. cfm? \&ID $=3943 \& N L=61>$.

Newsholme, C. 1992. Willows: The genus Salix. Timber Press, Portland, OR.

Stahl, L. 2004. Woody decorative florals. 23 Nov. 2009. <http://ruraladvantage. org/pdf/3rdCropOps-WoodyOrnamentals. pdf $>$.

U.S. Department of Agriculture. 2008. Cooperative State Research, Education, and Extension Service. Specialty crop initiative. 23 Nov. 2009. <http://www.csrees.usda. gov/fo/specialtycropresearchinitiative.cfm $>$. 